\title{
Growth, Production, and Bean Quality of Coffea arabica as Affected by Interspecific Grafting: Consequences for Rootstock Breeding
}

\author{
Benoît Bertrand ${ }^{1}$ and Hervé Etienne \\ Centre de Coopération Internationale en Recherche Agronomique pour le \\ Développement/ Instituto Interamericano de Cooperación Agrícola- \\ (Programa Cooperativo Regional para el Desarollo Tecnológico y \\ Modernización de la Caficultura en Centramerica y Caribe), CIRAD/IICA/ \\ PROMECAFE, Ap 55, 2200 Coronado, San José, Costa Rica
}

\section{Albertus Eskes \\ Centre de Coopération Internationale en Recherche Agronomique pour le Développement (CIRAD), BP 5035, 34032 Montpellier Cedex 01, France}

Additional index words. Coffea canephora, Coffea liberica, incompatibility, yield, sensorial analysis

\begin{abstract}
In order to avoid nematode damage to roots of Coffea arabica L. in Latin America, a common practice is interspecific grafting on $C$. canephora var. Robusta (Pierre) rootstocks. The performance of two $C$. arabica cultivars, 'Caturra' and 'Catimor T5175', was evaluated on four rootstocks: $C$. canephora var. Robusta ('T3561' and 'T3757') and C. liberica var. liberica (Hiern) and var. dewevrei (Lebrun), over 5 years in a trial at $1180 \mathrm{~m}$ elevation in Costa Rica. Nongrafted plants of the two Arabica cultivars were used as controls. Mortality of plants grafted on the two $C$. liberica cvs. was $>20 \% \mathrm{vs}$. $6 \%$ to $13 \%$ for plants grafted on C. canephora, and $3 \%$ to $4 \%$ for the two controls. Analysis of accumulated yields over four harvests showed that the rootstocks limited stem girth and reduced yield $10 \%$ to $48 \%$. Yield on the $C$. canephora rootstock was greater than that on the two $C$. liberica cultivars. However, grafting did not affect female fertility (peaberries, empty berries) or content of several chemicals, such as caffeine, fat, and sucrose. The two C. liberica rootstocks significantly reduced aroma and bean size. Histological studies revealed symptoms of incompatibility, characterized by more dilated and less distinct growth rings and appearance of plugged vascular connections. The poor performance of the rootstocks may therefore be explained by partial incompatibility. However, growth and productivity were also affected by poor adaptations of $C$. canephora, $C$. liberica, and $C$. dewevrei to the lower temperature at high altitudes and by morphological differences in the root systems. These results emphasize the need to develop better adapted rootstock cultivars from $C$. canephora var. Robusta.
\end{abstract}

Grafting of coffee to reduce nematode injury is a well-developed practice in Latin America. In Guatemala, hypocotyledonary grafting has been used on a large scale for $>30$ years. Villain et al. (1996) observed that with heavy Pratylenchus sp. infestations, production of Arabica plants grafted on a C. canephora var. Robusta rootstock was four times as great as that of nongrafted plants. In the presence of heavy Meloidogyne incognita (Chitwood) infestations in Brazil, Da Costa et al. (1991)

Received for publication on 13 Dec. 2000. Accepted for publication 30 June 2000. We appreciate the technical support granted by the Board of ICAFE of Costa Rica and express our gratitude to Philippe Vaast for reviewing the manuscript. The cost of publishing this paper was defrayed in part by the payment of page charges. Under postal regulations, this paper therefore must be hereby marked advertisement solely to indicate this fact.

${ }^{1}$ To whom reprint requests should be addressed. Email address: benoit.bertrand@ cirad.fr. observed that production of plants grafted on Robusta was three to four times greater than that of nongrafted plants. In addition to being used to increase resistance to soilborne parasites, grafting is also commonly used for fruit trees and in silviculture to improve tree adaptation to unfavorable soil or climatic conditions. There is abundant information in the literature on rootstock-scion interactions that affect vigor and productivity. Such results have been reported for apple (Malus xdomestica Borkh.) (Shechter et al., 1991) and peach (Prunus persica L.) (Bussi et al., 1996; Glucina et al., 1992; Layne et al., 1976). The rootstock can also influence fruit size (Ogasanovic and Papic, 1995) and leaf nitrogen and amino acid contents (Doroshenko, 1992). Physical or translocated incompatibilities can occur immediately or over time. Translocated incompatibility (Herrero, 1955), also called biochemical incompatibility, is reflected in reduced starch in the rootstock, or accumu- lation of toxic phenolic compounds in the union.

Interspecific grafting of Coffea sp. has been studied for its potential benefits in preserving fragile genetic resources and improving resistance to nematodes. Couturon (1993) reported no incompatibility between C. arabica and 10 other Coffea species at 600 m elevation: the best species for vigor and low mortality were $C$. liberica and $C$. canephora. In India, Raghuramulu and Thimmaraju (1998) reported excellent compatibility between $C$. arabica and C. canephora and C. liberica var. devewrei.Partial incompatibility was detected with $C$. liberica var. liberica, confirming previous field observations (Cramer, 1957). In Indonesia, Nur (1984) reported differences in growth among $C$. arabica plants grafted on Robusta rootstocks from several sources. In a Brazilian study evaluating the efficiency of nematode control via grafting, Melo et al. (1976) detected no difference in caffeine content between Arabica grafted on Robusta and nongrafted controls.

No studies are known in which the influence of rootstock on coffee bean quality has been evaluated. The objectives of this study were to: 1) evaluate the effect of interspecific grafting on yield and bean quality of Arabica coffee produced in an area with optimum growing conditions; and 2) obtain information on how to improve the selection of rootstock cultivars.

\section{Materials and Methods}

Plant material. The plant material used in this study is described in Table 1. Grafting was carried out with two Coffea arabica cultivars $(2 \mathrm{n}=4 \mathrm{x}=44)$ used as scions, and rootstocks from two diploid $(2 \mathrm{n}=2 \mathrm{x}=22)$ species of Coffea using Reyna's hypocotyledonary grafting technique (1966). The Arabica cultivars were 'Caturra', widely produced in Latin America, and 'Catimor T5175', a new cultivar resistant to leaf rust (Hemileia vastatrix Berk. et $\mathrm{Br}$.) that yields $20 \%$ to $25 \%$ more than does 'Caturra'. The rootstocks were from openpollinated progenies of the following diploid species: C. canephora var. Robusta(Froehner); $C$. liberica var. liberica (Hierns); and $C$. liberica var. dewevrei (Lebrun) Lebrun. In this study, the latter two species are referred to as $C$. liberica and $C$. dewevrei, respectively. Note that these two subspecies reach a height of $>6-$ $8 \mathrm{~m}$ and a stem girth between 80 and $130 \mathrm{~cm}$ under free growth conditions, whereas $C$. canephora reaches a height of 4-5 $\mathrm{m}$ and 40 $75 \mathrm{~cm}$ in girth, and C. arabica cultivars $2-3 \mathrm{~m}$ in height and $20-30 \mathrm{~cm}$ in girth. Following grafting, plants were grown in plastic bags under greenhouse conditions for 7 months before being planted in the field.

Experimental design. The trial was set up in June 1992, at the Coffee Research Centre (CICAFE), Heredia, Costa Rica, at $1180 \mathrm{~m}$ elevation, with an annual average temperature of $20.5^{\circ} \mathrm{C}$, on an Andosol soil, and with 2200 $\mathrm{mm}$ of annual rainfall. The experimental design consisted of seven randomized treatments, with single-tree plots, and 25-35 replicates 
Table 1. Origins of scions and rootstocks.

\begin{tabular}{|c|c|c|c|c|c|c|}
\hline Scion & Origin & Source & Rootstock & Origin & Source & $\begin{array}{c}\text { No. trees } \\
\text { studied }\end{array}$ \\
\hline T5175 (Catimor) & CIFC HW 26/13 & ICAFE & Nongrafted (control) & --- & ICAFE & 35 \\
\hline T5175 (Catimor) & CIFC HW 26/13 & ICAFE & Robusta, T3561 (2-1) & Rep. of Congo, L48 & CATIE & 25 \\
\hline Caturra & Brazil & ICAFE & Nongrafted (control) & 1 & ICAFE & 35 \\
\hline Caturra & Brazil & ICAFE & Robusta, T3757 (1-2) & Indonesia SA-13 & CATIE & 30 \\
\hline Caturra & Brazil & ICAFE & Robusta, T3561 (2-1) & Rep. of Congo, L48 & CATIE & 33 \\
\hline Caturra & Brazil & ICAFE & Liberica, T3718 (1-1) & Africa & CATIE & 33 \\
\hline Caturra & Brazil & ICAFE & Dewevrei, T3446 (1-1) & Puerto Rico & CATIE & 29 \\
\hline
\end{tabular}

(trees). Plant spacing was $2 \mathrm{~m}$ between rows and $1 \mathrm{~m}$ within rows. The trial was conducted without shade. Plants received $1000 \mathrm{~kg} \cdot \mathrm{ha}^{-1}$ of $18 \mathrm{~N}-3 \mathrm{P}-10 \mathrm{~K}-8 \mathrm{Mg}-0.5 \mathrm{~B}$ fertilizer annually, split into two applications in May and August, $250 \mathrm{~kg} \cdot \mathrm{ha}^{-1}$ of $\mathrm{N}$ in November, and two foliar applications per year of copper hydroxide (1.5 $\mathrm{kg} \cdot \mathrm{ha}^{-1}$ ) to prevent leaf and fruit diseases.

Growth. Stem girth (10 $\mathrm{cm}$ above ground level) was measured 17 and 66 months after planting, and total height of the stem and average length of the two longest branches after 66 months. After the fourth harvest, the trees were cut back to $20 \mathrm{~cm}$ above ground level. New shoots were counted five months later and classified according to their growth status, using a scale of $1-5$, where $1=$ poor development and 5 = good development. Ability to produce shoots after stumping was estimated by an index of stumping response (shoot number $\times$ shoot quality). Six months after stumping, when the trees had resprouted well, samples of 20 leaves were collected from a total of 10 trees from each grafting combination and the control. Content of $\mathrm{N}, \mathrm{K}, \mathrm{Mg}, \mathrm{Ca}$, $\mathrm{Al}, \mathrm{Zn}$, and $\mathrm{Cu}$ was analyzed. Nitrogen was determined by the Kjeldahl method (Jones and Case, 1990) and other elements by atomic absorption spectrometry. Phosphorus was quantified by spectrometry at $660 \mathrm{~nm}$, following a colorimetric method with molybdenum blue. Data are expressed in percentage of dry matter.

At the end of the experiment, all the plants were carefully removed to study their root systems. Number and length of taproots and abundance of secondary roots were evaluated on a scale of $1-5$, where $1=$ very few roots and $5=$ abundant roots. For 10 plants from each graft combination and the control, the stem was cut crosswise for macroscopic observation of the graft union. A histological technique was used to observe the graft unions of two 'Caturra' trees grafted on: 1) Robusta 'T3561'; 2) Robusta 'T3757'; 3) C. liberica; and one control tree. All grafted trees observed were growing poorly. The graft union was cut into segments $2 \mathrm{~cm}$ long and a microtome was used to cut $25-\mu \mathrm{m}$ slices from the segments. The samples were fixed for $24 \mathrm{~h}$ in a solution of FAA and then dehydrated in an ethanol series (50-70-80-90-95-100-100\%) for 30 min each. Safranin (2\%) was added in $70 \%$ ethanol and fast green $(1 \%)$ in $100 \%$ ethanol for $15 \mathrm{~s}$. The slices were placed in a solution of 1 absolute ethanol : 1 xylene for $30 \mathrm{~s}$ and then in pure xylene ( $2 \times$ for $30 \mathrm{mn}$ each) (Sass, 1958), before being examined under the microscope.
Fertility and yield. Cumulative yields (grams of fresh berries per tree) of surviving trees over 4 years were recorded. Coffee berries normally contain two seeds, but abortion of one ovule during early fruit development gives rise to one round seed, called peaberry (Van der Vossen, 1985). Another postzygotic abortion can occur when the fruit has attained its final size. This late abortion gives rise to one or two empty locules, causing the berry to float when immersed in water (De Reffye, 1975). The berries from the last three harvests were scored for: 1 ) fraction of peaberries in a subsample of 100 green fruits collected 6 months after flowering from the eight most heavily bearing nodes; 2) fraction of floating berries in a subsample of 200 ripe fruits after immersion in water; and 3) fraction of beans in a subsample of $2 \mathrm{~kg}$ of green coffee retained by a size 17 sieve ( $6.65 \mathrm{~mm}$ round holes).

Chemical analyses and cup quality tests. The effects of grafting on chemical composition and organoleptic properties were studied for 3 consecutive years (the second, third, and fourth harvest years). Samples of $250 \mathrm{~g}$ of green coffee were collected after screening through a size 17 sieve and eliminating most defective beans. Sucrose, chlorogenic acid, caffeine, trigoneline, and fat contents were obtained by chemical analysis after grinding the beans, following the method of Guyot et al. (1988). The analysis were achieved by near infrared spectrometry by reflectance of green coffee after grinding (ground to $<0.5 \mathrm{~mm}$ ). An NIR spectrometer system (model 6500; NIRSystem, Silver Spring, Md.) driven by NIRS2 (4.0) software (Intrasoft Intl. LLC, Port Matilda, Pa.). Each compound was evaluated using specific calibrations. Cup quality tests were carried out after controlled roasting (weight loss and color measurement) on an infusion prepared from $50 \mathrm{~g}$ of roasted coffee. A panel of eight persons tasted, under white light environment, $50-60-\mathrm{mL}$ samples kept at $50-60{ }^{\circ} \mathrm{C}$. The main taste and beverage attributes (aroma, body, acidity, bitterness, and astringency) were estimated using scales ranging from $0-5$, where $0=$ nil, $1=$ very light, $2=$ light, $3=$ regular, $4=$ strong, and $5=$ very strong. An additional preference score was used ranging from $0-5$, where $0=$ not good for drinking, 1 = very bad, $2=$ bad, $3=$ regular, 4 $=$ good, and $5=$ very good.

Statistical analysis. All data were subjected to a one-way analysis of variance (ANOVA) using SAS version 6.04 (SAS Institute, 1988). For categorical data, the normality of residuals and homoscedasticity were verified to about fulfill the conditions for
ANOVA. Duncan's multiple range test was used for mean separation. To improve comparisons, the 'Catimor T5175' control was compared with the 'Catimor T5175' grafted on Robusta 'T3561', while the 'Caturra' control was compared with other treatments. The differences were considered significant at $P \leq 0.05$.

\section{Results and Discussion}

Effects on mortality and growth. Mortality was higher for plants grafted on C. liberica, or C. dewevrei (Table 2) than for controls, whereas plants grafted on Robusta tended to show similar or slightly higher mortality than did the controls. 'Caturra' grafted on Robusta 'T3561' grew significantly better than did the other grafted plants; after 1 year in the field, the height and stem girth were not significantly different from that of nongrafted plants (Table 2). After 66 months of growth, the effect of grafting on stem girth remained unchanged. On average, plants grafted on $C$. canephora were taller whereas those grafted on $C$. liberica and $C$. dewevrei were shorter than the nongrafted controls. Plants with the strongest branch growth were the controls and 'Caturra' grafted on Robusta 'T3561', which again differed significantly from the remaining grafted plants.

Rootstocks also had a significant effect on quality and the number of resprouting shoots after stumping (Table 3). The 'Caturra' scions grafted on $C$. dewevrei had a significantly lower response index than did all other plants. As for chemical contents of the leaves, only the aluminum content differed significantly; aluminum content in leaves of trees on rootstocks that imparted low vigor was $23 \%$ higher. The root system was significantly affected by grafting in 'Caturra' (Table 3), nongrafted plants had a root system without a developed main taproot, but with several short pseudo-taproots and dense secondary roots. In contrast, the $C$. dewevrei and the $C$. liberica rootstocks had one or two very large taproots with a low density of secondary roots. The Robusta rootstocks were intermediate. The roots of 'T3561' resembled those of 'Caturra', while the roots of 'T3757' behaved like $C$. dewevrei roots. The root systems of $C$. dewevrei and $C$. liberica and, to a lesser extent, of Robusta 'T3757', differed from that of 'Caturra'. The presence of a deep taproot associated with a low density of fine roots, affects soil exploration and consequently nutrient uptake capacity. This may explain the much higher leaf aluminum contents for the 
Table 2. Effects of rootstock on mortality, growth, and production of two scion cultivars of coffee.

\begin{tabular}{|c|c|c|c|c|c|c|c|}
\hline \multirow[b]{2}{*}{ Scion/rootstock } & \multirow{2}{*}{$\begin{array}{c}\text { Mortality } \\
(\%)\end{array}$} & \multicolumn{2}{|c|}{ Trunk girth $(\mathrm{cm})$} & \multirow{2}{*}{$\begin{array}{l}\text { Height } \\
(\mathrm{cm})\end{array}$} & \multirow{2}{*}{$\begin{array}{c}\text { Branch length } \\
\text { (cm) }\end{array}$} & \multirow{2}{*}{$\begin{array}{c}\text { Fruit yield } \\
\text { (g/tree) }\end{array}$} & \multirow{2}{*}{$\begin{array}{l}\text { Coefficient of } \\
\text { variation }(\%)^{2}\end{array}$} \\
\hline & & $17 \mathrm{mo}$ & $66 \mathrm{mo}$ & & & & \\
\hline T5175 (control) & 2.9 & $7.5 \mathrm{a}^{\mathrm{y}}$ & $18.2 \mathrm{a}$ & $180 \mathrm{a}$ & $97.8 \mathrm{a}$ & $17593 \mathrm{a}$ & 32.7 \\
\hline T5175/T3561 (Robusta) & 13.3 & $5.8 \mathrm{~b}$ & $16.5 \mathrm{~b}$ & $187 \mathrm{a}$ & $87.7 \mathrm{~b}$ & $13718 \mathrm{~b}$ & 48.8 \\
\hline Caturra (control) & 4.0 & $7.3 \mathrm{a}$ & $18.1 \mathrm{a}$ & $183 \mathrm{ab}$ & $95.6 \mathrm{a}$ & $15772 \mathrm{a}$ & 38.7 \\
\hline Caturra/T3561 (Robusta) & 6.0 & $6.9 \mathrm{a}$ & $17.1 \mathrm{ab}$ & $198 \mathrm{a}$ & $94.0 \mathrm{ab}$ & $14106 \mathrm{ab}$ & 41.1 \\
\hline Caturra/T3757 (Robusta) & 13.3 & $5.7 \mathrm{ab}$ & $16.4 \mathrm{~b}$ & $185 \mathrm{a}$ & $83.7 \mathrm{a}-\mathrm{c}$ & $9786 \mathrm{~b}$ & 61.7 \\
\hline Caturra/C. liberica & 21.2 & $5.2 \mathrm{~b}$ & $16.4 \mathrm{~b}$ & $164 \mathrm{c}$ & $88.6 \mathrm{bc}$ & $9305 \mathrm{~b}$ & 67.5 \\
\hline Caturra/C. dewevrei & 20.7 & $5.0 \mathrm{~b}$ & $16.8 \mathrm{~b}$ & $171 \mathrm{bc}$ & $86.6 \mathrm{c}$ & $8130 \mathrm{~b}$ & 66.9 \\
\hline
\end{tabular}

${ }^{2}$ The coefficient of variation is based on the four cumulative yields.

${ }^{y}$ Mean separation within columns and scion cultivars by Duncan's multiple range test, $P \leq 0.05$.

Table 3. Effects on rootstock on growth after stumping, abundance of secondary roots, length of taproots, leaf aluminum content, and berry characteristics, of two scion cultivars of coffee.

\begin{tabular}{lccccccc}
\hline \hline Scion/rootstock & $\begin{array}{c}\text { Growth after } \\
\text { stumping }^{\mathrm{z}}\end{array}$ & $\begin{array}{c}\text { Abundance } \text { of }^{\mathrm{s}} \\
\text { secondary roots }\end{array}$ & $\begin{array}{c}\text { Length of } \\
\text { tap roots }(\mathrm{cm})\end{array}$ & $\begin{array}{c}\text { Aluminum } \\
\left(\mathrm{mg} \cdot \mathrm{kg}^{-1}\right)\end{array}$ & $\begin{array}{c}\text { Peaberries } \\
(\%)\end{array}$ & $\begin{array}{c}\text { Floating } \\
\text { berries }^{\mathrm{w}}(\%)\end{array}$ & $\begin{array}{c}\text { Heavy } \\
\text { beans }^{\mathrm{v}}(\%)\end{array}$ \\
\hline T5175 (control) & $14.5 \mathrm{a}^{\mathrm{u}}$ & $3.8 \mathrm{a}$ & $61 \mathrm{a}$ & $109.8 \mathrm{a}$ & $8.4 \mathrm{a}^{\mathrm{y}}$ & $7.6 \mathrm{a}$ & $49.3 \mathrm{a}$ \\
T5175/T3561 (Robusta) & $10.5 \mathrm{a}$ & $3.0 \mathrm{a}$ & $58 \mathrm{a}$ & $101.0 \mathrm{a}$ & $8.6 \mathrm{a}$ & $5.4 \mathrm{a}$ & $45.8 \mathrm{a}$ \\
Caturra (control) & $11.0 \mathrm{a}$ & $3.2 \mathrm{a}$ & $56 \mathrm{~b}$ & $101.5 \mathrm{~b}$ & $10.0 \mathrm{a}$ & $4.0 \mathrm{a}$ & $40.5 \mathrm{a}$ \\
Caturra/T3561 (Robusta) & $14.5 \mathrm{a}$ & $2.8 \mathrm{ab}$ & $48 \mathrm{~b}$ & $101.0 \mathrm{~b}$ & $9.6 \mathrm{a}$ & $2.8 \mathrm{a}$ & $36.7 \mathrm{a}$ \\
Caturra/T3757 (Robusta) & $12.5 \mathrm{a}$ & $2.1 \mathrm{~b}$ & $108 \mathrm{a}$ & $123.0 \mathrm{a}$ & $10.2 \mathrm{a}$ & $3.2 \mathrm{a}$ & $39.5 \mathrm{a}$ \\
Caturra/C. liberica & $11.5 \mathrm{a}$ & $1.8 \mathrm{~b}$ & $116 \mathrm{a}$ & $133.0 \mathrm{a}$ & $11.8 \mathrm{a}$ & $3.8 \mathrm{a}$ & $31.2 \mathrm{~b}$ \\
Caturra/C. dewevrei & $8.5 \mathrm{~b}$ & $2.0 \mathrm{~b}$ & $112 \mathrm{a}$ & $134.0 \mathrm{a}$ & $11.4 \mathrm{a}$ & $3.0 \mathrm{a}$ & $33.6 \mathrm{ab}$ \\
\hline
\end{tabular}

${ }^{\mathrm{z}}$ Shoot numbers $\times$ shoot quality. Shoot quality was scored according to a scale ranging from $1-5$, where $1=$ very poor growth and $5=$ very good growth.

${ }^{y}$ Scored according to a scale ranging from $1-5$, where $1=$ very few and $5=$ abundant roots.

${ }^{x}$ Fraction of peaberries in a subsample of 100 green fruits collected 6 months after flowering.

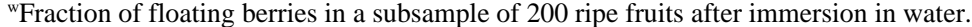

${ }^{\mathrm{v}}$ Fraction of heavy beans retained by a no. 17 screen.

"Mean separation within columns and scion cultivars by Duncan's multiple range test, $P \leq 0.05$.

three rootstocks with deep taproots. In this type of soil, aluminum content in fact increases in the lower horizons.

Effects on yield. The rootstocks induced variable and lower yields in comparison with those of the controls (Table 2). The Robusta 'T3561' rootstock reduced accumulated yield $10 \%$ and $22 \%$ in 'Caturra' and 'Catimor T5175', respectively. This effect was greater for the Robusta 'T3757' rootstock, with a $38 \%$ reduction. Coffea liberica and $C$. dewevrei rootstocks reduced yield $41 \%$ to $48 \%$, respectively, relative to 'Caturra'. Coefficients of variation were higher for the less productive combinations. Classification of treatments remained the same irrespective of the numbers of replicates considered (all plants or only the 10 best plants of each treatment). The higher production and vigor of nongrafted $C$. arabica cultivars with those grafted on the $C$. liberica or $C$. dewevrei and Robusta rootstocks was quite noticeable. These characteristics revealed themselves early on, resulting in lower mortality and a more rapid increase in stem height and girth. This difference was maintened in stem vigor and production for the whole productive cycle, although inter- and intraspecific differences in behavior were recorded. Coffea canephora (var. Robusta) was apparently more adapted to local conditions than were $C$. liberica and $C$. dewevrei. Within the Robusta species, the ' $\mathrm{T} 3561$ ', originating from Republic of Congo, was more adapted than was the 'T3757' from Indonesia. Yield of the latter was well below that of the controls. The $23 \%$ difference in yield between Robusta 'T3561' and Robusta 'T3757' can be explained mainly by the morphological differences in their root systems.

Effects on fertility and cup quality. The scions had significant effects on the number of peaberries and empty berries, whereas the rootstock did not significantly affect these two characteristics (Table 3). The scion also had a stronger influence on bean size than did the rootstock. Larger beans were produced on 'T5175' than on 'Caturra'. There was no effect of grafting on Robusta. In contrast, plants grafted on $C$. liberica and $C$. dewevrei tended to produce smaller beans (Table 3). Grafting had no effect on chlorogenic acid, trigoneline, caffeine and fat contents, nor did organoleptic tests reveal differences between grafted and nongrafted plants (Table 4), except for aroma, for which graft combinations with $C$. liberica and $C$. dewevrei were inferior to the control. The species used as rootstocks in the present study produce coffee of inferior quality, with a biochemical composition different from that of $C$. arabica; for example, the caffeine content ranges between $1.4 \%$ to $4 \%$ for Robusta and $1.0 \%$ to $1.8 \%$ for $C$. liberica vs. $0.8 \%$ to $1.2 \%$ for Arabica (Louarn, 1992). However, our study demonstrated that interspecific grafting did not affect biochemical composition or cup quality, although it affected bean size and

Table 4. Effects of rootstock on cup quality of coffee from two scion cultivars (average for 3 years).

\begin{tabular}{lllcccc}
\hline \hline Scion/rootstock & Aroma $^{z}$ & Body & Acidity & Bitterness & Astringency & Preference score \\
\hline T5175 (control) & $2.93 \mathrm{a}^{y}$ & $2.75 \mathrm{a}$ & $1.90 \mathrm{a}$ & $1.80 \mathrm{a}$ & $2.30 \mathrm{a}$ & $3.00 \mathrm{a}$ \\
T5175/T3561 (Robusta) & $2.93 \mathrm{a}$ & $2.70 \mathrm{a}$ & $1.75 \mathrm{a}$ & $2.85 \mathrm{a}$ & $2.15 \mathrm{a}$ & $2.75 \mathrm{a}$ \\
Caturra (control) & $2.90 \mathrm{ab}$ & $2.85 \mathrm{a}$ & $2.15 \mathrm{a}$ & $2.70 \mathrm{a}$ & $2.30 \mathrm{a}$ & $3.10 \mathrm{a}$ \\
Caturra/T3561(Robusta) & $3.20 \mathrm{a}$ & $3.15 \mathrm{a}$ & $2.00 \mathrm{a}$ & $3.25 \mathrm{a}$ & $2.45 \mathrm{a}$ & $3.10 \mathrm{a}$ \\
Caturra/T3757 (Robusta) & $3.40 \mathrm{a}$ & $2.55 \mathrm{a}$ & $1.75 \mathrm{a}$ & $2.85 \mathrm{a}$ & $2.00 \mathrm{a}$ & $3.50 \mathrm{a}$ \\
Caturra/C. liberica & $2.53 \mathrm{~b}$ & $2.65 \mathrm{a}$ & $1.75 \mathrm{a}$ & $2.80 \mathrm{a}$ & $2.10 \mathrm{a}$ & $2.80 \mathrm{a}$ \\
Caturra/C. dewevrei & $2.70 \mathrm{~b}$ & $2.60 \mathrm{a}$ & $1.75 \mathrm{a}$ & $2.85 \mathrm{a}$ & $2.20 \mathrm{a}$ & $2.75 \mathrm{a}$
\end{tabular}

${ }^{2}$ Scores for aroma, body, acidity, bitterness, and astringency estimated using scales ranging from $0-5$, where $0=$ nil and $5=$ very strong.

Preference score, $0-5$, where $0=$ nil and $5=$ very good. Data obtained from a panel of eight judges.

'Mean separation within columns and scion cultivars by Duncan's multiple range test, $P \leq 0.05$. 

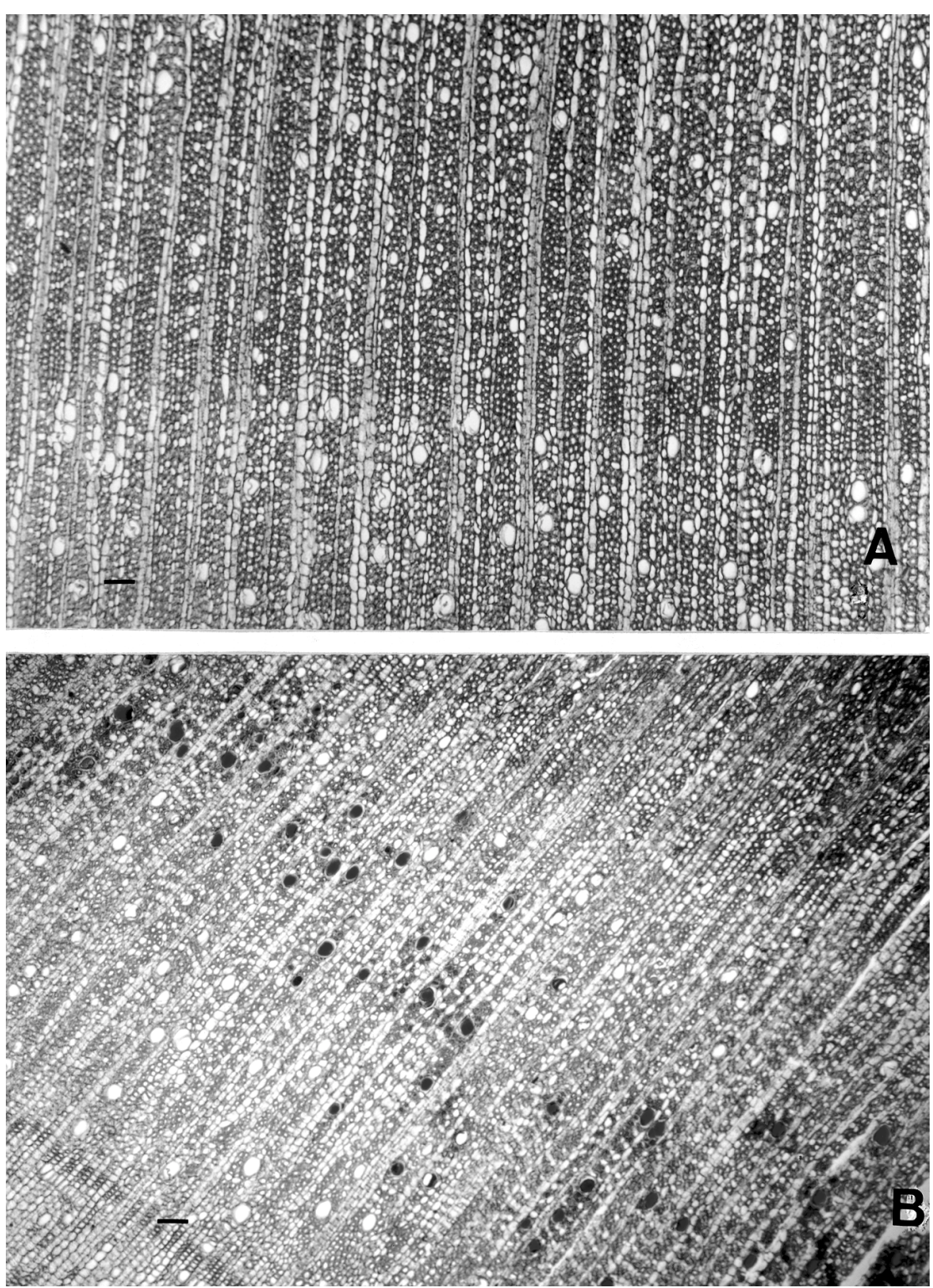

Fig. 1. Xylem vessels in (A) nongrafted 'Caturra' trunk and in (B) cross-section of graft union of 'Caturra' x C. liberica coffee. The black patches are plugged xylem vessels. Bar $=300 \mu \mathrm{m}$.

aroma. The factors that most affect bean size are water supply (Suárez-Serrato, 1978) and bean : leaf ratio (Cannell, 1974). Poor vegetative growth on $C$. liberica and $C$. dewevrei explains their effects in reducing bean size.

Scion/rootstock compatibility. More than half the plants grafted on $C$. dewevrei or $C$. liberica had thickened graft unions. This was probably the result of differences in growth rate, hence in diameter, between rootstocks and scions rather than incompatibility. Macroscopic evaluation of longitudinal stem sections did not reveal any abnormalities at the graft union and there was no sign of necrosis. This confirms that there is no physical incompatibility in the combinations studied. Such results have been reported in early stages by Raghuramulu and Thimmaraju (1998) and by Couturon (1993). However, for the six trees chosen for poor growth, histological evaluation revealed differences between control and and $C$. liberica grow best in the humid tropics areas with average temperatures of $25^{\circ} \mathrm{C}$ or more. Reported exceptions are a C. canephora population well adapted to $1300 \mathrm{~m}$ elevation in Sudan and one C. liberica population on Mont Tonkoui at $1000 \mathrm{~m}$ in the Ivory Coast. Most indigenous populations are located between 300 and $600 \mathrm{~m}$. At lower temperatures, C. canephora tends to exhibit symptoms characteristic of cold lesions, with poor plant growth and high mortality. For example, the average height of 100 plants from two C. canephora clones growing in a plot next to the trial described in this study (elevation $1180 \mathrm{~m}$ ) was $113 \mathrm{~cm}$ after 25 months. The same plants cultivated in a plot at $600 \mathrm{~m}$ reached a height of $174 \mathrm{~cm}$. Moreover, in low-lying areas, Arabica plants are more vigorous when grafted on Robusta than on their own roots (Couturon, 1993).

Rootstock breeding program. The morphology of the root system should become an important criterion when selecting new rootstock cultivars. The strong correlation observed between stem girth at 17 months and yield $\left(r^{2}=0.76\right)$ (data not shown) also shows that early selection of rootstocks is possible. For further rootstock breeding programs, the simultaneous use of four criteria is recommended: 1) juvenile mortality; 2) stem girth at 15-20 months; 3) morphology of the root system; and 4) resistance to soilborne parasites.

Given these results, interspecific grafting at optimum altitude for Arabica (elevation 1000-1300 m), with average temperatures between 20 to $23^{\circ} \mathrm{C}$, is recommended only in the presence of highly pathogenic nematodes. This is a very common situation in Guatemala and El Salvador for extensive areas located at elevations $>1000 \mathrm{~m}$. In the case of infestation with less pathogenic species (i.e., M. exigua Goeldi, Bertrand et al., 1998), resistance of the rootstock may not compensate for the loss of productivity. Grafting on Arabusta (C. arabica $x$ C. canephora) interspecific hybrid rootstocks $(2 \mathrm{n}=2 \mathrm{x}=44)$ is worth considering as an alternative. In Africa, the high vigor of Arabusta has been recorded at elevations ranging from 400 to $1000 \mathrm{~m}$. A program has been initiated in Central America to develop an Arabusta rootstock. Following in vitro multiplication through somatic embryogenesis of two parents selected for their resistance to Meloidogyne sp., a Robusta tetraploid produced by colchicine application and a male-sterile Ethiopian accession, field plots will be established to produce seeds of a new Arabusta cultivar. At low altitudes, grafting on Robusta or other Coffea sp. should be studied for its potential in adapting Arabica coffee to marginal conditions. In Central America, the Nemaya cultivar, an excellent rootstock for controlling soilborne parasites (Bertrand et al., 2000), is now available to producers.

\section{Literature Cited} the nongrafted plants, even when considering only the best ten plants in each combination. The occurrence of such incompatibility is probably temperature-related. Both $C$. canephora
Bertrand, B., O. Borbon, and G. Aguilar. 1998. Situación nematológica en un cafetal de la meseta central de Costa Rica y posibilidades de control, 
p. 15-29. In: ICAFE de Costa Rica (eds.). Memoria III Seminario Resultados y Avances de Investigación.

Bertrand, B., M.X. Peña Durán, F. Anzueto, C. Cilas, H. Etienne, F. Anthony, and A.B. Eskes. 2000. Genetic study of Coffea canephora coffee tree resistance to Meloidogyne incognita nematodes in Guatemala and Meloidogyne sp. in El Salvador for selection of rootstock varieties in Central America. Euphytica 113:79-86.

Bussi, C., J. Besset, and A. Duc. 1996. Incidence du porte-greffe sur la croissance et la fructification du pêcher (Prunus persica (L.) Batsch). Fruits 50:125-132.

Cannell, M.G.R. 1974. Factors affecting Arabica coffee bean size in Kenya. J. Hort. Sci. 49:65-76.

Couturon, E. 1993. Mise en évidence de différents niveaux d'affinité, des greffes inter-spécifiques chez les caféiers, p. 209-217. In: Proc. 15th Intl. Sci. Colloq. on Coffee. 6-11 June, 1993. Montpellier, France. Assn. Sci. Intl. du Café (eds.),Vevey, Switzerland.

Cramer, P.J.S. 1957. A review of literature of coffee research in Indonesia. Inter-Amer. Inst. of Agr. Sci., Turrialba, Costa Rica.

Da Costa, W.M., W. Gonlçalvez, and L.C. Fazuoli. 1991. Produçao do café Mundo Novo em portaenxertos de Coffea canephora em area infestada com Meloidogyne incognita raça 1. Nematol. Brasileira 15:43-50.

Doroshenko, T.N. 1992. Changes in the content of nitrogen compounds in leaves and roots of apple trees with different stock/scion combinations and productivity (in Russian). Sel'skokhozyaistvennaya Biologiya 1:81-87.
Glucina, P.G., R.S. Mills, and P.J. Manson . 1992. Comparison of the growth, yield, fruit size and survival of 'Golden Queen' peach on seven rootstocks. N.Z. J. Crop Hort. Sci. 20:297-303.

Guyot B., E. Petnga, and J.C. Vincent. 1988. Analyse qualitative d'un café, Coffea canephora var. Robusta en fonction de la maturité . Café Cacao Thé 32:127-139.

Herrero J., 1955. Studies of compatible and incompatible graft combinations with special reference to hardy fruit trees. J. Hort. Sci. 26:186-237.

Jones J.B. and V. Case. 1990. Soil testing and plant analysis. Book Series 3. 3rd ed., p. 414. In: Soil Sci. Soc. of Amer., Madison, Wis.

Layne, R.E.C, G.M. Weaver, H.O. Jackson, and F.D. Stroud. 1976. Influence of peach seedling rootstocks on growth, yield and survival of peach scion cultivars. J. Amer. Soc. Hort. Sci. 101:568572 .

Louarn, J. 1992. La fertilité, des hybrides interspécifiques et les relations agronomiques entre caféiers diploides d'origine Africaine (genre Coffea L.). Thèse d'Univ., Paris-Sud, Orsay.

Melo, M., A. Carvalho, and L.C. Monaco. 1976 Contribution of the rootstock to the caffeine content of coffee beans. Bragantia 35:55-61.

Nur, A.M. 1984. Effect of rootstocks on growth and leaf mineral composition of Robusta coffee. Menara Perkebunan 52:65-70.

Ogasanovic, D. and V. Papic 1995. Effect of Prunus tomentosa on the vigor and productivity of some plum cultivars and hybrids (in Serbian). Jugoslovensko Vocartvo 29:51-57.

Raghuramulu, Y. and K.R. Thimmaraju. 1998. Early observations on graft compatibilty between com- mercial arabica coffee cultivars and desirable rootstocks. Plantations, Recherche, Développement 5:41-46.

Reffye (de), Ph. 1975. Le contrôle de la fructification et de ses anomalies chez les $C$. arabica, Robusta et leurs hybrides 'Arabusta', p. 459-482. In: Proc. Intl. Sci. Colloq. on Coffee. 9-14 June 1975. Hamburg, Germany. Assn. Sci. Intl. du Café, Vevey, Switzerland.

Reyna, E.H. 1966. La técnica del injerto hipocotiledonar del cafeto para el control de nematodos del Café. Café (Lima, Peru) 7:5-11.

SAS Institute Inc. 1988. SAS/STAT user'guide. Release 6.04 eds. SAS Inst., Cary, N.C.

Sass, J.E. 1958. Botanical microtechniques. 3rd ed. Iowa State Univ. Press.

Schechter, I., D.C. Elfving, and J.T.A Proctor. 1991. Canopy development, photosynthesis and vegetative growth as affected by apple rootstocks. Fruit Var. J. 45: 229-237.

Suárez-Serrato, J.V. 1978. Influencia de la precipitación en el crecimiento del fruto de café Avances técnicos de CENICAFE 89:1-4

Van der Vossen, H.A.M. 1985. Coffee selection and breeding, p. 48-96. In: M.N. Clifford and K.C. Willson (eds.). Coffee: Botany, biochemistry and production of beans and beverage. Croom Helm, London.

Villain, L., J.L. Sarah, B. Decazy, A. Molina, and S. Sierra. 1996. Evaluation of grafting on Coffea canephora var. Robusta, and chemical treatment for control of Pratylenchus sp in C. arabica cropping systems, p. 407-422. In: Proc. 3rd Intl. Nematol. Congr. Gosier, Guadeloupe, 7-12 July 1996. 